\title{
Towards a Framework for Analysing Notions of Education Quality in Different Teacher Education Orientations
}

\author{
Dr Yvonne Nsubuga \\ Faculty of Education, University of Fort Hare \\ Private Bag X1314, Alice, 5700, South Africa \\ ynsubuga@ufh.ac.za
}

\section{Doi:10.5901/mjss.2014.v5n7p381}

\begin{abstract}
While the need improve the quality of teacher education is widely acknowledged, there has been limited critical engagement with notions of education quality in different teacher education orientations and their implications for teacher education policy and practice. This article proposes an analytical framework to help unearth core education quality issues and questions in different teacher education orientations. The article also describes the application of the proposed framework to two selected teacher education orientations, namely the human capital and the capabilities approaches. Results showed that the economic 'lens' of the human capital orientation narrows the range of education quality issues and questions that can be raised within this orientation. On the other hand, due to its comprehensive and multidisciplinary nature, the capabilities approach is able to bring to the fore education quality issues and questions that cover a wider scope of not only educational processes and outcomes but also of dimensions of human well-being and flourishing, and was thus able to provide a more nuanced understanding of quality in teacher education than the human capital perspective. Implications of the results of the analysis for teacher education reform are also briefly discussed.
\end{abstract}

Keywords: teacher education orientations, education quality, analytical framework, human capital approach, capabilities approach

\section{Introduction}

\subsection{Why focus on teacher education quality?}

It is widely acknowledged that teacher quality is one of the most important school-related factors that contribute to learner achievement (UNESCO, 2007; Wang, Odell, Klecka and Lin, 2010; UNICEF/UNESCO, 2011). Worldwide, the demand for quality teachers has reached unprecedented levels as the crucial role that they play towards effective learning and the realisation of democratic and socio-economic ideals becomes apparent (McLeskey and Ross, 2004; Yates, 2007; UNESCO, 2005). In the South African context, numerous studies have cited poor teacher quality as one of the key factors that are responsible for the general poor performance of pupils at the majority of rural and township schools, especially in the crucial subjects of Mathematics and Science, and for the ineffective implementation of transformative post-apartheid curriculum policies at school and classroom levels (Taylor and Vinjevold, 1999; Cross, Mungadi \& Rouhani, 2002; Dada, Dipholo, Hoadley, Khembo, Muller \& Volmink, 2009).

South Africa's most recent policy document on teacher education the Integrated Strategic Planning Framework for Teacher Education identified quality as one of the six key principles that should underpin the design of teacher education programmes in the country (Department of Basic Education and Department of Higher Education and Training, 2011:23). The quest for quality in teacher education in South Africa also forms the basis of the European Union-funded Strengthening Foundation Phase Teacher Education Project which aims to improve teaching and learning in the country's Foundation Phase classrooms (The Cape Consortium, 2010). Other examples of strategies and measures that have been put in place to improve the quality of teacher education in South Africa include the formulation of new teacher education policies, the incorporation of teacher education into the Higher Education sector, re-accreditation of teacher education programmes, the setting of standards for teacher education, and the establishment of quality assurance mechanisms at national and institutional levels (Robinson, 2003; Schafer \& Wilmot, 2012).

However, while the urgent need for quality in teacher education remains undisputed, there is less clarity on the type of teacher education that this entails. Compared to mainstream education, there has been limited research and public debate of issues that contribute to quality in teacher education. Furthermore, so far, most teacher education research has tended to focus on structural, organisational and curricular aspects, leaving the philosophical principles and 
assumptions that underpin policy and practice in this field mostly under-researched and unquestioned (Tuinamuana, 2007; Deng and Gopinathan, 2003). While the view that different stakeholders hold different conceptualisations of education quality, depending on their contexts, assumptions, goals and desired outcomes is well established in literature (UNESCO, 2005; 2011), this discussion has been conducted mostly within the general schooling system framework, and the extension of the debate to the teacher education field has attracted less public and academic attention. The debate on quality in teacher education is further compounded by the fact that there is no common agreement on what the basic knowledge of initial teacher education ought to be (Papier, 2008: 8), which has contributed to what Wang, Lin, Spalding, Klecka and Odell (2011:331) call a 'kaleidoscope' of understandings of quality in the teacher education field.

Different philosophical understandings of quality within teacher education have important implications for teacher education policies and practice, as well as for the strategies and procedures that are used in maintaining and monitoring the quality of teacher education programmes. According to Graham and Barnett (1996:161), the views and beliefs that we hold regarding teacher education quality not only impinge on what we believe to be the core activities of teacher education practice, but also on teachers' professional identities. With teacher education being high on the priority list of most governments, it is important that conceptualisations of quality in this field and the assumptions on which are they are based are critically interrogated through public debate and research.

\subsection{Article aims}

This paper has two main aims. Firstly, it proposes a framework for critical analysis of notions of education quality that are embedded in different teacher education orientations. The second aim is to demonstrate how the proposed analytical framework can be operationalized, by applying it to two teacher education orientations, namely the human capital (HC) and the Capabilities Approach (CA). Overall, the paper attempts advance critical analysis of understandings of quality in different teacher education orientations, in addition to making contribution to coherence between teacher education policy and practice.

The paper is organised into three main sections. The first section provides an overview of the HC and CA teacher education orientations with the aim of outlining their key characteristics and their implications for education. The $\mathrm{HC}$ orientation was selected for analysis because of its dominant position in the teacher education arena, while the CA represents an important emerging orientation whose implications for teacher education are yet to be fully investigated. The second section of the paper outlines the structure of the proposed analytical framework, and how it was derived. The third section of the paper is an attempt at operationalizing the proposed framework by applying it to the two teacher education orientations, with the aim of bringing to the fore pertinent relevant education quality issues and questions in each of the two teacher education orientations. The aim is not to present an exhaustive list of education quality issues and questions in each orientation, but rather to provide insight into the major issues and questions that should foreground the debate on quality in each of the two selected teacher education orientations.

\section{Teacher Education Orientations}

A teacher education orientation or paradigm is defined in Deng and Gopinathan (2003: 51) as a particular way of conceiving teacher education that is based on a set of assumptions that offer guidance as to the core activities that define teacher education. Feiman-Nemser (1990) refers to teacher orientations as reflecting differing views about the goals of teacher education and how to achieve them. Various researchers categorise teacher education orientations differently, for example Deng and Gopinathan (2003), Tuinamuana (2007), Yates (2007), and Menter, Hulme, Elliot and Lewin (2010). This paper adopted the teacher education typology that was proposed by Yates (2007:3) which differentiates between the $\mathrm{HC}$, human rights, critical, and what he calls (post) post-modernism, of which the CA is an example. It needs to be stressed, however, that such categorisation is mainly for analytical purposes, and that considerable overlapping and hybridisation between the different teacher education orientations occurs not only at institutional level but also at programme or course level (Reid \& O'Donoghue, 2004; Tuinamuana, 2007).

\subsection{The human capital orientation}

Proponents of $\mathrm{HC}$ theory regard humans as an economic production factor that is invested in, in order to contribute to higher economic productivity and growth (Robeyns, 2006). Education is valued for its role in developing workers' competences such as knowledge, attitudes and skills, which is believed to have a positive effect on individuals' productivity levels, earnings and national economic growth. The HC to education has gained prominence worldwide amid 
growing concerns over efficiency and transparency in the education system, and the need to achieve high rates of returns in investment in education by minimising educational costs while at same time maximizing educational output (Lazano, Boni, Peris \& Hueso, 2012). In narrow interpretations of HC, teacher education has two main roles. Firstly, it serves to enable student teachers and their pupils to acquire the competencies that are valued in the labour market. Secondly, the field aims to equip student teachers with the know-how of effectively transferring these competencies to their pupils in the classrooms (pedagogical knowledge). Richards (1989) notes that in this orientation, teacher education is a form of training, in which novice teachers are expected to match their teaching styles to that which is regarded as effective and successful.

There are numerous limitations associated with a $\mathrm{HC}$ rationale for teacher education. In Tikly (2011), and Tilky and Barrett (2011) HC theory is critiqued for advancing an input-output model of education, with scant attention being paid to the learning needs of individuals and the contexts under which learning and teaching take place. Being top-driven, this orientation to teacher education is based more on theory rather than on what actually takes place inside the classroom, and disempowers teachers from being in charge of their learning (Richards 1989: 3). The orientation is associated with a focus on the observable and measurable aspects of teaching and learning at the expense of those that are less tangible, such as teachers' belief and value systems. It supports a prescribed standardised curriculum, where teacher education goals and objectives, the content of teacher educational programmes and pedagogies to be used are determined externally (often at national level), independent of the specifics of teacher education institutions, those of student teachers and of the schools where teachers eventually serve. The approach also favours didactic teaching approaches, including teacher-centred lessons, prescribed teacher education support materials, and privileges test and examination scores as a measurement of effective teaching and learning (Tikly, 2010). Robeyns (2006:69) blames HC theory for advocating a fragmented, instrumentalist and economistic approach to education, and by extension, teacher education, while side lining education's non-economic and intrinsic values.

\subsection{The Capabilities approach}

Attempts to counteract the strong influence of $\mathrm{HC}$ theory in education, together with the need to address its short comings have seen the emergence of several alternative education discourses, examples of which include the human rights, social justice, critical, and the CA. Compared to the other alternative orientations, the CA is relatively new and its implications for education are yet to be fully theorised or researched (Saito, 2003). Nevertheless, the approach is slowly making inroads into mainstream education thinking, where it is providing a different 'lens' through which to examine education polices and practice.

The CA is based on the central argument that rather than accumulation of resources (resourcism) or increase in levels of happiness and desire fulfilment (utilitarialism), what is intrinsically important to human development is the range of options or freedom (termed capabilities) that individuals have access to, to enable them live the kind of life they aspire to (Sen, 1992; Dreze \& Sen, 1995). The aim of human development is believed to be twofold: to expand an individual's freedom to lead the type of life he or she values; and to remove obstacles that limit an individual's life options (Robeyns, 2003:6). The shift from the HC focus on economic productivity and employability to that of capabilities places the individual and their states and actions right at the centre of human development efforts, which has implications for all forms of education including teacher education.

In the capabilities perspective, the notion of education and its aims and outcomes are more multidimensional and complex than in HC discourse (Unterhalter, Vaughan \& Walker, 2007). Firstly, education is described as a basic capability, in the sense that without it one's ability to achieve desired life options is curtailed. Secondly, good education is believed to contribute to the expansion of higher and more complex capabilities (Saito, 2003:29), especially those that foster reflection, deep understanding, and informed decision making. A core educational question in this approach is 'Does the education provided offer individuals equal educational opportunities for them to realise what they value in life? Arguing that capabilities can either be put to good or bad use, Saito (2003) suggests that education should also help develop individuals' value systems in making informed decision on how to put to good use the capabilities that they have access to. Although Sen (1999) regards capabilities as contextual and best arrived at through a public participatory process, several researchers have attempted to draw up a list of basic capabilities that are necessary for human wellbeing, the most well-known being that by Nussbaum (2000:78-80). Several researchers have adapted Nussbaum's list of basic capabilities to different education contexts including higher education. For example, Walker (2006b:128-129) identified eight basic capabilities that would ensure human well-being and human dignity in the higher education sector, namely practical reason; educational resilience; knowledge and imagination; learning disposition; social relations and social networks; respect, dignity and recognition; emotional integrity; and bodily integrity. However, there is a dearth of 
literature on capabilities that specifically relate to teacher education.

In addition to capabilities, the CA's other core concepts, namely functionings, agency freedom, agency achievement, human diversity, and conversion factors also provide alternative 'lenses' through which to conceptualise, analyse and evaluate educational issues. Functionings are closely allied to capabilities in that they represent the valued human states and activities (beings and doings) that are actually achieved, or what an individual manages to be and do (Sen 1999:75). For example, being able to learn how to swim or how to read are capabilities, while the ability to swim or the joy of reading a novel are examples of functionings. Other examples of functionings include being numerate, knowledgeable, healthy, well-fed, well dressed, commanding respect among peers, having high self-esteem, good citizenship, and political participation (Sen 1999:75). The range of potential functionings is huge. However, HC theory focuses on the realisation of economic functionings, and the CA argues that valued functionings can come from any dimension of human well-being, including the spiritual, emotional, moral, social and political. From an educational perspective, the CA places value on all benefits that accrue from education, including those that are non-instrumentalist or are intrinsic. In addition education is believed to develop individuals' perception of valued functionings and life options beyond for example examination scores and employability, as advanced by HC theory (Unterhalter, Vaughan \& Walker, 2007).

The CA places emphasis on human agency since the lack or restricted agency limits one's ability to act on desired goals and achieve valued functionings. Lozano, Boni, Peris and Hueso (2012:134) describe agency as being an active participant in planning and conducting one's life. While agency freedom is the range of opportunities available to pursue and bring about valued goals or functioning (Tao, 2009: 3), agency achievement describes the extent to which those desired goals or functionings are actually achieved (Walker, 2004:2). Seen from these perspectives, education's role is to contribute to the expansion of agency (empowerment) to enable individuals to become autonomous and be authors of their own lives (Lozano, Boni, Peris and Hueso, 2012). Lopez-Fogues (2012:73) concludes that in the CA, education's role transcends that of preparing for employment, and involves unleashing of human agency in order to provide individuals with the ability to shape their own future (Lopez-Fogues, 2012:73).

According to Sen $(1992,1999)$, income and other resources are important not as ends, but because they can be converted into capabilities and ultimately into valued functionings that constitute human well-being. From an educational perspective, the CA alerts us to not only ask whether educational resources such as textbooks and computers are available, but also to inquire whether individuals are able to convert them into capabilities and valued educational functionings. The ability to convert resources into capabilities and functioning is influenced by what Sen calls conversion factors, which are divided into personal conversion factors (sex, age, physical and mental abilities, education levels), social conversion factors (social practices and cultural norms) and environmental factors (climatic conditions and geographical location). Hence unlike $\mathrm{HC}$ theory, the CA pays special attention to the learning and teaching context as well as the pedagogical processes when evaluating education. In addition the CA takes into account human diversity not only in the choice of valued functionings, but also in the ability to convert the same resources into capabilities and functionings.

Critiques levelled against the CA are mainly associated with difficulties in its operationalization. In Clark (2005:6) it is noted that the CA is under-developed, over individualistic, does not provide guidance on identification and weighting of different capabilities, and has extremely high information requirements. Unterhalter, Vaughan and Walker (2007) note that application of the CA to educational context is challenged by difficulties associated with identification and measurement of individuals' life aspirations, especially in children.

\section{Structure of the Proposed Analytical Framework}

Based on the descriptions of the two teacher education orientations outlined above, and on other published literature, four inter-linked dimensions were identified as being essential to the critical analysis of teacher education orientations with the aim of interrogating embedded notions education quality (see Table 1). The table also provide a brief rationale for the selection of these particular dimensions. 
Table 1: Structure of the analytical framework

\begin{tabular}{|l|l|}
\hline Dimension & Rationale \\
\hline $\begin{array}{l}\text { Philosophical views on } \\
\text { human development }\end{array}$ & $\begin{array}{l}\text { Human development contributes to the realisation of individual and collective development ideals } \\
\text { (UNESCO, 2012: 9), however these may be conceptualised and defined. }\end{array}$ \\
\hline $\begin{array}{l}\text { Goals and objectives of } \\
\text { teacher education }\end{array}$ & $\begin{array}{l}\text { Views on what education is expected to deliver are contextual, value-laden and shaped by underlying } \\
\text { beliefs and philosophical assumptions (UNESCO, 2005). }\end{array}$ \\
\hline $\begin{array}{l}\text { Effective pedagogic } \\
\text { processes }\end{array}$ & $\begin{array}{l}\text { The major recognised education traditions are informed by different teaching and learning theories, and } \\
\text { conceptualise effective teaching and learning processes differently (UNESCO, 2005). }\end{array}$ \\
\hline $\begin{array}{l}\text { Curriculum structure and } \\
\text { content }\end{array}$ & $\begin{array}{l}\text { Differing views on curriculum reflect underlying philosophical beliefs and assumptions. How curriculum } \\
\text { is conceptualised and understood influences the decisions that are made about its goals, structure, } \\
\text { content and development (Prevedel, 2003). }\end{array}$ \\
\hline
\end{tabular}

\section{Major Education Quality Issues and Questions in Teacher Education}

The four dimensions of the analytical framework and the characterisations of the HC and the CA to teacher education were used to identify key issues and questions that relate to education quality in each of the two teacher education orientations. These issues and questions represent what should drive the education quality debate in the $\mathrm{HC}$ and $\mathrm{CA}$ teacher education orientations, and are illustrated in Table 2 and Table 3, respectively.

Table 2: A summary of key education quality issues and questions within the human capital orientation to teacher education

\begin{tabular}{|c|c|c|}
\hline Dimension & Core Issues & Core Questions \\
\hline $\begin{array}{l}\text { Views on human } \\
\text { development }\end{array}$ & $\begin{array}{l}\text { Contribution of teacher education to } \\
\text { national productivity and economic } \\
\text { growth }\end{array}$ & $\begin{array}{l}\text { - To what extent is teacher education contributing to higher national } \\
\text { - } \text { - What are rates of return on investments in teacher education? } \\
\text { - How is teacher education helping to address challenges such as the } \\
\text { critical skills shortage in Mathematics, Science and technology that } \\
\text { hinder economic growth? } \\
\text { - What is the articulation between the country's teacher education } \\
\text { - system and its vision for economic development? } \\
\text { and earnings? }\end{array}$ \\
\hline $\begin{array}{l}\text { Goals and objectives } \\
\text { of teacher education }\end{array}$ & $\begin{array}{l}\text { Development of competencies } \\
\text { (knowledge, skills and values) that } \\
\text { foster increased productivity, higher } \\
\text { wages and economic development }\end{array}$ & $\begin{array}{l}\text { - To what extent do the teacher education goals and objectives relate to } \\
\text { the development of competences that foster higher individual } \\
\text { productivity and earning, and contribute to national economic } \\
\text { development? } \\
\text { - To what extent do the goals and objectives of teacher education } \\
\text { articulate with the national and global socio-economic agenda? }\end{array}$ \\
\hline $\begin{array}{l}\text { Effective pedagogic } \\
\text { processes }\end{array}$ & $\begin{array}{l}\text { For transferring, acquisition and } \\
\text { demonstration of mastery of } \\
\text { competencies that foster increased } \\
\text { productivity, higher wages and } \\
\text { economic development. }\end{array}$ & $\begin{array}{l}\text { - How effective are teacher educators in transferring prescribed } \\
\text { - Hompetencies to student teachers? } \\
\text { competencies? } \\
\text { - How effective are teacher education pedagogical processes in } \\
\text { developing the prescribed competences among student teachers? } \\
\text { - How effective are current formal assessment practices in monitoring } \\
\text { the acquisition of the prescribed competences by student teachers? }\end{array}$ \\
\hline $\begin{array}{l}\text { Curriculum structure } \\
\text { and content }\end{array}$ & $\begin{array}{l}\text { An externally prescribed curriculum } \\
\text { with fixed curriculum content. }\end{array}$ & $\begin{array}{l}\text { - To what extent is the teacher education curriculum externally } \\
\text { - How effectively is the prescribed curriculum implemented at } \\
\text { institutional level? } \\
\text { - Are prescribed teacher education resources available to support } \\
\text { curriculum implementation? } \\
\text { - To what extent does the prescribed content foster the development of } \\
\text { competencies that are valued by the labour market? }\end{array}$ \\
\hline
\end{tabular}


Table 3: A summary of key education quality issues and questions in the Capabilities Approach to teacher education

\begin{tabular}{|c|c|c|}
\hline Dimension & Core Issues & Core Questions \\
\hline $\begin{array}{l}\text { Views on human } \\
\text { development }\end{array}$ & $\begin{array}{l}\text { Expansion of individual student } \\
\text { teachers' capabilities. } \\
\\
\text { Individual student teachers' } \\
\text { achievement of valued ways of being } \\
\text { and doings (functionings) }\end{array}$ & $\begin{array}{l}\text { - What capabilities is teacher education providing access to? Do all } \\
\text { student teachers enjoy equal access to these capabilities? } \\
\text { - What are individual student teachers' valued functionings? How is } \\
\text { teacher education addressing individual student teachers' valued } \\
\text { functionings? } \\
\text { - How is teacher education enabling student teachers to voice their } \\
\text { valued functionings? } \\
\text { - What conversion factors affect student teachers' ability to convert } \\
\text { resources into capabilities, and capabilities into valued functionings? } \\
\text { How are these factors being addressed in current teacher education } \\
\text { policy and practice? }\end{array}$ \\
\hline $\begin{array}{lr}\text { Goals } & \text { and } \\
\text { objectives of } \\
\text { teacher education }\end{array}$ & $\begin{array}{l}\text { Expansion of individual student } \\
\text { teachers' capabilities. } \\
\text { Removal of obstacles that limit } \\
\text { individual student teachers' access to } \\
\text { capabilities and expansion of their } \\
\text { capabilities. } \\
\text { Fostering of agency freedom and } \\
\text { agency achievement among individual } \\
\text { student teachers. }\end{array}$ & $\begin{array}{l}\text { - How is teacher education contributing to the expansion of individual } \\
\text { student teachers' capabilities? } \\
\text { - How effective are teacher educators in expanding student teachers' } \\
\text { capabilities? } \\
\text { - How effective are graduate teachers in expanding their pupils' } \\
\text { capabilities? } \\
\text { - How is teacher education contributing to the removal of obstacles to } \\
\text { the realisation of valued functionings among individual student } \\
\text { teachers? } \\
\text { - How is teacher education contributing to agency freedom and } \\
\text { agency achievement among individual student teachers? }\end{array}$ \\
\hline $\begin{array}{l}\text { Effective pedagogic } \\
\text { processes }\end{array}$ & $\begin{array}{l}\text { Contribution to the expansion student } \\
\text { teachers' capabilities sets } \\
\text { Contribution to the realisation of } \\
\text { student teachers' valued functionings } \\
\text { Contribution to student teachers' } \\
\text { agency freedom and agency } \\
\text { achievement. } \\
\text { Removal of obstacles to access to } \\
\text { education, and to expansion of } \\
\text { student teachers' capabilities }\end{array}$ & $\begin{array}{l}\text { - How effective are teacher education pedagogic processes in } \\
\text { expanding individual student teachers' capabilities? } \\
\text { - How are teacher education pedagogic processes contributing to the } \\
\text { realisation of individual student teachers' valued functionings? } \\
\text { - How are the teacher education pedagogical processes supporting } \\
\text { agency freedom and agency achievement among individual student } \\
\text { teachers? } \\
\text { - How are pedagogical processes in teacher education addressing } \\
\text { heterogeneity issues among student teachers? } \\
\text { - How effective is assessment in teacher education in monitoring the } \\
\text { achievement of valued functionings and agency among student } \\
\text { teachers? }\end{array}$ \\
\hline $\begin{array}{l}\text { Curriculum } \\
\text { structure } \\
\text { content }\end{array}$ & $\begin{array}{l}\text { Open and flexible curriculum } \\
\text { Locally relevant curriculum content } \\
\text { that is sensitive to individual student } \\
\text { teachers' needs and aspirations }\end{array}$ & $\begin{array}{l}\text { - How is the content of teacher education curriculum contributing to } \\
\text { the expansion of student teachers' capabilities? } \\
\text { - How is the content of teacher education curriculum contributing to } \\
\text { the removal of obstacles to the realisation of valued functionings of } \\
\text { individual student teachers? } \\
\text { - How is the teacher education curriculum supporting the development } \\
\text { and exercising of agency, and the realisation of valued functionings } \\
\text { among individual student teachers? } \\
\text { - How are the teacher education materials supporting the development } \\
\text { and exercising of agency and the realisation of valued functionings } \\
\text { among student teachers? } \\
\text { - How effective are the assessment strategies used in teacher } \\
\text { education in supporting and monitoring the expansion of capabilities, } \\
\text { development and exercising of agency, and the realisation of valued } \\
\text { functionings among individual student teachers? }\end{array}$ \\
\hline
\end{tabular}




\section{Discussion}

The various orientations that characterise teacher education are underpinned by different philosophical beliefs on a range of fundamental issues which include human development, goals and objectives of education, effective pedagogic processes, and curriculum structure and content. These issues interact with each other to shape how quality is understood in each teacher education orientation, and how it is best monitored and evaluated. However, while it is common practice for teacher education institutions to clearly articulate their preferred teacher education orientation, for example in their mission and vision statements, rarely is there specific mention of, or in-depth engagement with conceptualisations of education quality. In most cases, conceptualisations of quality are implicitly implied rather than being explicitly stated. This is a serious omission given the multiple and contested nature of the concept of education quality, and the fact that different teacher education orientations can co-exist in the same teacher education institution, let alone in the same teacher education programme. The side lining of conceptualisations of quality in teacher education discourse increases the likelihood of mismatch between teacher education goals and their enactment at institution or programme level. The analytical framework that is proposed in this paper represents an attempt at designing a practical tool that can be used to enhance teacher educators' and other key stakeholders' ability to critically engage with conceptualisations of education quality in different teacher education orientations. The analytical tool is also intended to contribute to the emerging literature on education within a capabilities framework.

There are two key points to make about the structure of the analytical framework that is proposed in this paper. Firstly, all understandings of quality in teacher education are rooted in basic philosophical views and assumptions about human development. This is mainly because of the strong link between education quality, education relevance and responsiveness to human development needs (UNESCO, 2012:9). The close link between human development views and conceptualisations of teacher education quality underscores the importance of clarifying views on human development when planning and implementing teacher education policies and programmes. Secondly, although the remaining constitutive dimensions of education quality are separately presented in the proposed framework, in real life, there are interactive and iterative relationships between them, and between them and the underlying human development views and assumptions. This means changes made to teacher education goals alone will not be sufficient to effect the necessary shift in how quality in teacher education is understood, interpreted and practiced: appropriate changes also have to be made to the accompanying pedagogical processes, curriculum approach, structure and content.

A comparison of conceptualisations of education quality between the two teacher education orientations that were analysed revealed that not only does the CA raise more core issues and question on education quality than the $\mathrm{HC}$ approach, but also that these issues and questions cover a wider scope than those raised by HC theory. This is not surprising given the HC's limited economist views of human development and benefits of education. The CA, on the other hand, takes into account all dimensions of human well-being, as well as the instrumental and intrinsic values of education. In addition the CA pays attention to contextual factors (as conversion factors), and influence of human heterogeneity and individual agency in determining one's life style options, which are mostly side lined in the $\mathrm{HC}$ orientation. As a result, the CA is able to raise issues and questions that provide a more comprehensive and more nuanced understanding of quality in teacher education than the $\mathrm{HC}$ orientation.

Another striking difference in conceptualisations of education quality between the $\mathrm{HC}$ and $\mathrm{CA}$ is the occurrence of many issues and questions in the latter which cover concepts that are 'new' to education quality discourse and are likely to be unfamiliar to the general public (for example capabilities, functionings and conversion factors). Some of these concepts are also best researched and answered from a qualitative perspective, for example the identification and expansion of capabilities that are provided by teacher education, the assessment of students' access to these capabilities and of students' achievement and exercising of agency. In contrast, the CA raises mostly input and output related issues and questions that are also more tangible and measurable, for example the amount of financial investment in teacher education, the extent of acquisition of market-related competencies among student teachers, and the contribution of teacher education to higher earnings. The qualitative nature of many of the education quality issues and questions that are raised by the CA is likely pose a challenge in the identification of suitable indicators to monitor education quality in this teacher education orientation.

Another difference that was revealed during the course of the study is that while implications of HC theory for quality pedagogical processes and curriculum are well researched and established in literature, the same cannot be said of the capabilities orientation. Initial contributions to conceptualisations of pedagogy within a capabilities framework include 'rich learning' that incorporates learning as connection, construction and consequence (Yates, 2007: 3), a 'mutual pedagogy' that reinforces student and teacher interactions (Murpy and Wolfenden, 2013), and a 'praxis pedagogy' that is underpinned by principles of equity, democracy and criticality (Walker, 2008). Nevertheless much about the implications 
of the CA for quality in teacher education practice and curriculum is yet to be fully investigated. Alexander (2008) stresses the importance of the nature of pedagogical processes in shaping quality in education. With the CA now becoming a buzz word, there is a risk that planners and implementers of teacher education programmes are embracing the principles of CA into their mission statement and educational goals without paying heed to the far reaching implications for teaching and learning processes, as well as curriculum design, that this orientation to teacher education entails. This highlights the urgent need for more investigation into what effective pedagogical processes and curriculum design mean within a capabilities teacher education framework.

Lastly, as pointed out earlier, different orientations to teacher education may co-exist together in a given teacher education institution or teacher education programme. This is a potential source of inherent tension since (as this paper has shown) different teacher orientations correspond with different education quality discourses, and by implication different understandings of quality in teacher education practice, as well as quality assurance approaches and strategies. The challenge for teacher education policy makers and implementers is how to effectively deal with this tension so that there is logic and coherence in teacher education policy and practice. It is towards this end that this paper aimed to contribute: by bringing to the fore key issues and questions that are core to the quality debate in different teacher education orientations as an initial step towards better conceptual clarity and informed decision-making in teacher education reform.

\section{Conclusions}

The achievement of quality Education for All hinges on teacher education that is of high quality. Given the contested nature of the concept of education quality, and the existence of different orientations to teacher education, it is crucial that understandings teacher education quality are brought to the surface for clarification and debate. The analytical framework that is proposed in this paper is intended to be used as a tool by teacher educators and other stakeholders to help identify issues and questions that are central to conceptualisations of quality in different teacher education orientations. Application of the proposed analytical tool to the $\mathrm{HC}$ and $\mathrm{CA}$ teacher education orientations revealed striking differences in terms of the number, range and nature of key education quality issues and questions. The quality issues and questions raised in the $\mathrm{HC}$ orientation were mostly from an economic perspective, while the application of a CA 'lens' allowed for a more qualitative and multi-disciplinary analysis of quality in teacher education. This paper described the operationalization of the suggested analytical tool for only two teacher education orientations, and there is a need to extend the application of the tool to other teacher education orientations.

\section{References}

Alexander, R. 2008. Education For All. The quality imperative and the problem of pedagogy. [Online] Available: http://www.createrpc.org/pdf_documents/PTA20.pdf (July 21, 2011)

Clark, A. D. 2005. The Capability Approach: Its development, critiques and recent advances[Online] Available : http://www.amarc.org/documents/articles/GPRG_The_Capability_Approach.pdf (April 9, 2011)

Cross, M., Mungadi, R. and Rouhani, S. 2002. From policy to practice: Curriculum reform in South African Education. Comparative Education, 38,171-187.

Dada, F., Dipholo, T., Hoadley, U., Khembo, E., Muller, S. and Volmink, J. 2009. Report of the task team for the review of the implementation of the National Curriculum Statement. [Online] Available: http://www.futureentrepreneurs.co.za/uploads Inews_docs/NCS_FINAL_DRAFT_REPORT_092409.pdf (August 8, 2011)

Deng, Z., Gopinathan, S. 2003. Continuity and change in conceptual orientations for teacher preparation in Singapore: Challenging teacher preparation as training. Asia-Pacific Journal of Teacher Education, 31, 51-65.

Department of Basic Education and Department of Higher Education and Training. 2011. Integrated Strategic Planning framework for teacher education and development. Technical Report. [Online] Available: www.education.gov.za (January 17, 2012)

Drèze, J. and Sen, A. 1995. India: Economic Development and Social Opportunity. Delhi: Oxford University Press.

Fieman-Nemser, S. 1990. Conceptual orientation in teacher education. [Online] Available: http://education.msu.educ/NCRTL/PDFs (April $7,2012)$

Graham, J. and Barnett, R. 1996. Models of quality in teacher education. Oxford Review of Education, 22,161- 178.

Lazano. J. F., Boni, A., Peris,J., and Hueso, A. 2012. Competencies in higher education: A critical analysis from the capabilities approach. Journal of Philosophy of Education, 46, 133-147.

McLeskey, J. and Ross, D. 2000. The politics of teacher education in the new millennium: Implications for special education teacher educators. Teacher Education and Special Education, 27,342-349.

Menter, I., Hulme, M., Elliot, D., and Lewin, J. 2010. Literature review of teacher education in the 21st Century. [Online] Available: http://www.schoolleadership.eu/sites/default/files/literature_review_on_teacher_8.pdf (July 21, 2012) 
Murphy, P. and Wolfenden, F. 2013. Developing pedagogy of mutuality in a capability approach- teachers' experiences of using the open educational resources (OER) of the teacher education in sub-Saharan Africa (TESSA) programme. International Journal of Educational Development, 33, 263-271.

Nussbaum, M. 2000. Women and human development: The capability approach. Cambridge: Cambridge University Press.

Papier, J. 2008. Policy, practices and persistent traditions in teacher education: the construct of teaching and learning regimes. Journal of Education, 45,7-28.

Prevedel, A. 2003. Values and beliefs: The world views behind curriculum. Focus on Basics, 6,8-12.

Reidi, A. and O'Donoghue, M. 2004. Revisiting enquiry-based teacher education in neoliberal times. Teaching and Teacher education, 20,559- 570.

Richards, J. C. 1989. Beyond training: Approaches to teacher education. A keynote address given at a workshop on $2^{\text {nd }}$ Language Teacher education. Macquarie University, Sydney, 15 June 1989.

Robeyns, I. 2003. Sen's capability approach and gender inequality: Selecting relevant capabilities. Feminist Economics, 9, 61-91.

Robeyns, I. 2006. Three models of education: Rights, capabilities and human capital. Theory and Research in Education, 4, 69-84.

Robinson, R. 2003. Teacher education in South Africa: The voice of teacher educators. Journal of Education for teaching, 29, 19-34.

Saito, M. 2003. Amartya Sen's capability approach to education: A critical exploration. Journal of Philosophy of Education, 37, 17-33.

Schafer, M., and Wilmot, D. 2012. Teacher education in post-apartheid South Africa: Navigating a way through competing state and global imperatives of change. [Online] Available: http://6-link.springer.com.warn.seals.ac.za (December 23, 2012)

Sen, A.K. 1992. Inequality re-examined. Oxford: Oxford University Press.

Sen, A.K. 1999. Development as Freedom. Oxford: Oxford University Press.

Tao, S. 2009. Applying the capability approach to school improvement interventions in Tanzania. [Online] Available: http://edqual.org/publications/workingpaper/edqualwp11.pdf (December 8, 2011)

Taylor, N. and Vinjevold, P. 1999. Getting learning right: Report to the President's Education Initiative Research Project. Johannesburg: Joint Education Trust.

Terzi, L. 2004. On education as a basic capability. [Online] Available : http://cfs.unipv.it/ca2004/papers/terzi.pdf (January 14, 2012)

The Cape Consortium. 2010. Quality teaching and teacher education practice. The Cape Foundation Phase Research Programme, Rhodes University: Grahamstown.

Tikly, L. 2011. Towards a framework for researching the quality of education in low income countries. Comparative Education, 47, 1-23.

Tikly, L. and Barrett, A.M. 2011. Social justice, capabilities and the quality of education in low-income countries. International Journal of Education Development, 31, 3-14.

Tuinamuana, K. 2007. Reconstructing dominant paradigms of teacher education: Possibilities for pedagogical transformation in Fiji. AsiaPacific Journal of Teacher Education 35, 111-127.

UNESCO. 2005. Education for All: The quality imperative. EFA Global Monitoring Report, Paris: UNESCO.

UNESCO. 2007. Teacher education policy forum for sub-Saharan Africa: Report. [Online] Available : http://unesdoc.unesco.org/images/0016/001627/162798e.pdf (April 9, 2011)

UNESCO. 2011. Beyond the conceptual maze: The notion of quality in education. Available : http://unescodoc.org (March 8, 2012)

UNESCO. 2012. General education system quality analysis/diagnosis framework (GEQAF. [Online] Available: http://www.unesco.org/new/en/education/themes/strengthening-education-systems/quality-framework/background/ (May 6, 2013)

UNICEF/ UNESCO 2011. Imperative for quality for all in Africa: Ensuring equity and enhancing teacher quality. [Online] Available : http://www.un.org/en/ecosoc/newfunct/pdf/background_paper-imperative_for_quality_education_for_all_in_africa.pdf (December 11, 2012)

Unterhalter, E., Vaughan, R., and Walker, M. (2007). The capability approach and education. [Online] Available: http://www.nottingham.ac.uk/educationresearchprojects/documents/developmentdiscourses/rpg2008walkermclean9.pdf (September 16, 2012)

Vigeant, L. 2013. International obligations: A comparison of the capabilities and basic rights models of education. [Online] Available: http://www.philosophy-of-education.org/uploads/2013\%20Conference/Papers/Vigeant.pdf ( January 14, 2014)

Walker, M. 2004. Insights from and for education: The capabilities approach and South African girls' lives and learning. [Online] Available: http://cfs.unipv.it/ca2004/papers/walker.pdf (April 21, 2011)

Walker, M. 2006. Towards a capability-based theory of social justice for education policy-making. Journal of Education Policy, 21,163185.

Walker, M. 2008. A human capabilities framework for evaluating student learning. Teaching in higher education, 13,477-487.

Wang, J., Lin, E., Spalding, E., Klecka, C.L., and Odell, S. J. 2011. Quality teaching and teacher education: A kaleidoscope of notions. Journal of Teacher Education, 62, 331-338.

Wang, J., Odell, S.J., Klecka, C.L., Spalding, E., and Lin, E. 2010. Understanding teacher education reform. Journal of Teacher Education, 61,395-402.

Yates, C. 2007. Teacher education policy: International development discourses and the development of teacher education. [Online] Available: http://unesdoc.unesco.org/images/0015/001557/155738e.pdf (August 28, 2012) 